
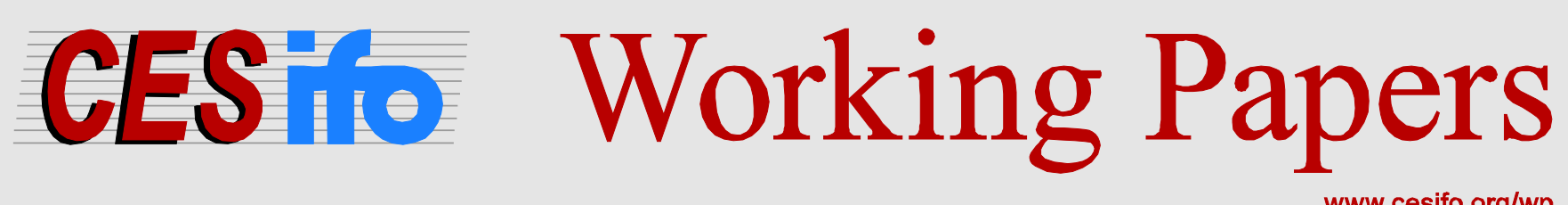

www.cesifo.org/wp

\title{
Political Institutions and Income (Re-)Distribution: Evidence from Developed Economies
}

\author{
Lars P. Feld \\ Jan Schnellenbach
}

CESIFO WORKING PAPER NO. 4382

CATEgory 2: Public CHOICE

August 2013

\footnotetext{
An electronic version of the paper may be downloaded

- from the SSRN website: $\quad$ www.SSRN.com

- from the RePEc website: $\quad$ www.RePEc.org

- from the CESifo website: www.CESifo-group.org/wp
}

\section{CESifo}




\title{
Political Institutions and Income (Re-)Distribution: Evidence from Developed Economies
}

\begin{abstract}
We discuss the effect of formal political institutions (electoral systems, fiscal decentralization, presidential and parliamentary regimes) on the extent and direction of income (re-) distribution. Empirical evidence is presented for a large sample of 70 economies and a panel of 13 OECD countries between 1981 and 1998. The evidence indicates that presidential regimes are associated with a less equal distribution of disposable incomes, while electoral systems have no significant effects. Fiscal competition is associated with less income redistribution and a less equal distribution of disposable incomes, but also with a more equal primary income distribution. Our evidence also is in line with earlier empirical contributions that find a positive relationship between trade openness and equality in primary and disposable incomes, as well as the overall redistributive effort.
\end{abstract}

JEL-Code: D310, H220, H110, H500, I380, P500.

Keywords: redistribution, formal institutions, fiscal decentralization, presidential and parliamentary regimes, electoral systems.

Lars P. Feld

Albert-Ludwigs-University Freiburg

Walter Eucken Institute

Goethestrasse 10

Germany - 79100 Freiburg

feld@eucken.de
Jan Schnellenbach

University of Heidelberg \&

Walter Eucken Institute Freiburg

Goethestrasse 10

Germany-79100 Freiburg

schnellenbach@eucken.de 


\section{Introduction}

An extensive public choice and political economy literature has studied the redistributive outcomes of political decision-making (Mueller 2003; Harms and Zink 2003; Feld and Schnellenbach 2007). An influential part of the earlier and primarily theoretical literature has been concerned with matters of budget incidence and the question of who benefits most from government activities. Propositions such as Director’s Law (Stigler 1970) have been formulated, which states that the middle classes are particularly favored by redistributive policies. This proposition runs counter as to what policy-makers usually claim to be the main direction of their redistributive efforts. The direction of income redistribution has, however, become much less of a concern in the recent literature, compared to the question whether the overall magnitude of redistribution varies with alternative constitutional designs (Persson and Tabellini 2000, 2003).

In this paper, we shed additional light on the political economics of income redistribution in democratic countries. Our particular emphasis is on the effects of different political institutions on the state's capacity to redistribute. We investigate the impact of electoral systems and of systems of government on the final distribution of income in a cross section of 70 countries during the years 1990 to 1998 . We find a weakly significant positive association between presidential regimes and inequality in disposable incomes, but no evidence of a statistically significant relation between electoral systems and inequality. In order to investigate the association between fiscal decentralization and income inequality, we use panel data for 13 OECD countries between 1981 and 1998 from the Luxembourg Income Study, which allows us to distinguish between inequality in market and after-tax disposable incomes. Furthermore, we use decentralization measures that capture actual tax autonomy on the sub-central level.

We find robust and highly significant evidence for a negative relation between sub-central tax autonomy and total redistribution. However, we also find that sub-central autonomy is associated with more equality in the distribution of primary incomes, and that revenue decentralization affects redistribution positively if we take sub-central revenue from fiscal equalization schemes into account. These findings are in line with the theoretical prediction that fiscal competition reduces the scope for redistribution because of taxpayers' mobility, while federal systems, that emphasize cooperation between jurisdictions and provide for substantial revenue through intergovernmental transfers, appear to facilitate redistribution. 
In Section 2, hypotheses regarding the impact of political institutions are outlined. The additional structure added to the analysis by institutions allows for more clear-cut theoretical hypotheses. A brief survey of redistribution policies in selected countries is presented in Section 3. New empirical evidence is presented and discussed in Section 4. Section 5 contains some concluding remarks.

\section{Political institutions and income redistribution}

\subsection{Presidential and parliamentary democracy}

The most important institutional difference between presidential and parliamentary democracies is that in presidential regimes, the government does not depend on a stable parliamentary majority. Instead, divided governments occur frequently. This implies that the head of government in a presidential regime is not able to use the threat of a vote of confidence as a tool for aligning the majority coalition in parliament with the position of the government (Huber 1996). One possible consequence is a lack of legislative cohesion in presidential regimes. It becomes more difficult to enforce an overarching policy framework in presidential as compared to parliamentary regimes. In the former, policy is thus an outcome of competition between relatively narrow special interests, which can also form spontaneous coalitions.

Persson and Tabellini (2000: ch. 10) argue that presidential regimes will typically be characterized by less total spending than parliamentary regimes. The reason is that in the former, taxing and spending decisions are often made in independent parliamentary committees. Those representatives sitting on the budget committee, who decide on the overall size of the budget, therefore expect that they will not be too influential in the decisions on the spending of public funds, which are made in separate spending committees. In fact, the agenda setter in the spending committee can channel most of the funds to his preferred use, since the institutional setting leads to a Bertrand type of competition. Other representatives offer their approving votes to the agenda setter in return for small budget shares, just to become part of the majority coalition and at least receive some spending on their preferred causes.

Anticipating this process in the spending committees, the agenda setter in the budget committee will propose a lean government, such that a lack of legislative cohesion leads to 
special-interest policy-making combined with a relatively small budget (Voigt 2011). The capacity to redistribute in the sense of large-scale general income-transfer schemes is thus reduced in presidential regimes. The remaining capacity is used to a lesser extent in a targeted fashion to reduce inequality, but to a greater extent in order to serve special interests (Kroszner and Stratmann 1998). These considerations imply the proposition that presidential regimes redistribute less income overall, but provide relatively more targeted redistribution than broad-based redistributive schemes which reduce inequality.

\subsection{Plurality rule and proportional representation}

Two mechanisms lead to a more narrow representation of interests in government under plurality rule, compared to proportional voting systems. The first is the low majority threshold. In the extreme, a government under plurality rule needs only a majority of 50\% plus one vote in $50 \%$ plus one of the districts, i.e., the support of $25 \%$ of the population. The second is the greater likelihood of a government that is supported by only one party. Duverger's Law, which is empirically well supported (e.g., Mueller 2003: ch. 13) in spite of some counter-examples such as the Liberal Democrats in Britain, predicts a convergence to a two-party system under plurality rule due to strategic voting. In this case, coalition governments become unnecessary and are seldom observed.

Plurality rule, like presidential regimes, can therefore be expected to produce more targeted policies catering to smaller constituencies, which closely resembles special-interest policymaking (Persson and Tabellini 1999, 2000). In countries with a middle class sufficiently strong and homogeneous to support a government, policies of the Director's Law type become more likely under plurality rule. Empirical evidence by Milesi-Ferreti et al. (2002) supports this proposition: For a panel of OECD countries, it is shown that broad transfer payments indeed increase with proportional representation. The effect of plurality rule on the overall magnitude of redistributive spending is, on the other hand, theoretically ambiguous. Persson and Tabellini (2000: ch. 8) predict a larger government under plurality rule, because the minority is often numerous and in many countries not institutionally protected from fiscal exploitation. On the other hand, cooperation of representatives in changing coalition governments under proportional representation may lead to smaller policy changes with changes of government, and thus also more stable policies of redistribution. Stability, in turn, may foster the growth of expenditures. Indeed, the empirical evidence so far suggests that proportional systems are characterized by more overall spending on income redistribution 
(e.g., Austen-Smith 2000; Persson and Tabellini 2003). It can thus be hypothesized that they generate less inequality in post-transfer incomes.

\subsection{Unitary and federal countries}

The main difference between unitary states and federations is often believed to be rooted in inter-jurisdictional competition. While unitary states are supposed not to allow for competition between jurisdictions, federations are assumed to be of the competitive type. This indeed holds for some key examples like the United States and Britain, but federations generally offer a variety of different organizational forms. The degree of actual decentralization that prevails in federal countries, and the extent of inter-governmental transfer schemes are important institutional details that should be taken into account. In addition, the regional level of a federation is formally represented in parliamentary decisionmaking at the federal level, providing for an additional element of checks and balances. In contrast, unitary states may allow for more competition at the local level of electoral districts, and the local rooting of representatives in the central parliament provides for some check on their decisions. It is thus useful to have a closer look at the actual extent of competition and cooperation between jurisdictions in a country instead of simply classifying countries as unitary states or federations.

In the extreme case of perfect competition among local governments, as analyzed by Tiebout (1956), (decentralized) redistribution becomes impossible. All taxes are Lindahl taxes, such that the equivalence between individual contributions and the utility enjoyed from locally supplied public goods is guaranteed. Sub-central redistribution is conceivable only with imperfect sorting of individuals into jurisdictions, and thus with heterogeneous local populations. Since earners of higher incomes are often particularly mobile and can more easily avoid taxation for redistributive purposes by relocating than lower income people, altruistic motives for redistribution along the lines of Pauly (1973) are often referred to in order to explain why sub-central redistribution is observed at all.

Even if the mobility of income taxpayers is imperfect, decentralization will reduce tax burdens and in particular the progressivity of the tax schedule (Sinn 2003). Sub-central governments competing for tax bases may even find it useful to experiment with regressive tax schedules, as some Swiss cantons have done in recent years. Regarding the other end of the income distribution, governments are tempted to deter transfer recipients from 
immigrating by offering only a modest level of transfer payments. There are, therefore, two expected effects of fiscal decentralization: a reduction of explicit transfer policies, and a tendency towards the equivalence principle for spending on other local public goods.

The effects of inter-governmental transfers or fiscal equalization schemes run in the opposite direction. The more generous they are, the less sub-federal jurisdictions are exposed to pressure from fiscal competition (Brennan and Buchanan 1980). The inter-governmental transfer payments offer sub-federal jurisdictions the possibility to allocate additional spending to schemes which redistribute incomes between individuals. This need not necessarily happen, as sub-federal policy-makers may decide to provide more local public goods. Nevertheless, fiscal equalization schemes could reduce the pressure inter-jurisdictional competition implies for sub-federal redistribution at least to some extent, because inter-jurisdictional transfers can either compensate for the reduction of tax rates induced by tax competition or allow to keep tax rates at a relatively higher level (Büttner 2006).

\section{How governments redistribute}

Before we start analyzing the relation between these political institutions and income redistribution econometrically, it is useful to have a closer at the redistributive activity of governments. Table 1 provides an overview over the share of social benefits in total government spending in a sample of OECD countries. These countries are representative for the continuum of redistributive spending shares found in the OECD.

Table 1: Overall Share of Expenditure on Social Benefits Including Social Transfers in Kind from Total Government Expenditure in 2010

\begin{tabular}{lc}
\hline Country & $48.8 \%$ \\
\hline Austria & $47.5 \%$ \\
Belgium & $37.7 \%$ \\
Finland & $53.3 \%$ \\
Germany & $35.0 \%$ \\
Sweden & $44.9 \%$ \\
Netherlands & $32.0 \%$ \\
Denmark & $35.0 \%$ \\
Norway & $13.7 \%$ \\
Israel & $15.2 \%$ \\
Iceland & $36.6 \%$ \\
Switzerland & $30.0 \%$ \\
United Kingdom & $36.8 \%$ \\
United States of America & (2012), National Accounts of OECD Countries, Online Database, OECD, Paris 2012. \\
\hline Source: OECD & \\
- We use the standard OECD measure for social benefits, which includes all social transfers in cash \\
and in kind provided by all levels of government and social security agencies. Total government \\
expenditure is aggregate spending of all levels of government and social security agencies.
\end{tabular}


The share of social spending from total spending varies considerably between countries from a bit less than $14 \%$ in Israel or $37 \%$ in the U.S. to $53.3 \%$ in Germany. These numbers alone are, however, not sufficiently informative as to the redistribution of income actually undertaken. Essentially, they show only that there is substantial variation between countries in the resources allocated to redistribution. Given the discussion since Director's Law, it is unclear whether these resources serve to redistribute income from the rich to the poor or not. In Table 2, countries are ordered according to their actually achieved degree of income equalization (fourth column). While Belgium almost cuts its inequality in primary incomes by half through redistribution, the United States reduce their primary inequality by less than a fourth. It is also striking that income redistribution in all countries relies mainly on transfers, rather than taxes. Looking at the relative importance of different transfer types, public pension systems apparently contribute a significant share to redistributive efforts in all countries.

Table 2: Income Distribution and Redistribution according to Gini-Coefficients, Selected OECD Countries in 2000

\begin{tabular}{lllllllll}
\hline & \multicolumn{2}{l}{ Gini coefficients } & \multicolumn{3}{c}{$\begin{array}{l}\text { Redistribution } \\
\text { from }\end{array}$} & \multicolumn{3}{c}{$\begin{array}{l}\text { Contribution of transfer types to } \\
\text { the reduction of inequality }\end{array}$} \\
\hline Country & Market & $\begin{array}{l}\text { Dispo- } \\
\text { sable }\end{array}$ & $\begin{array}{l}\text { Diffe- } \\
\text { rence }\end{array}$ & Taxes & $\begin{array}{l}\text { Trans- } \\
\text { fers }\end{array}$ & Pensions & $\begin{array}{l}\text { Unemploy- } \\
\text { ment } \\
\text { Benefits }\end{array}$ & \\
\hline Belgium & 0.465 & 0.242 & 0.223 & 0.062 & 0.161 & 0.107 & 0.023 & 0.030 \\
Sweden & 0.441 & 0.223 & 0.218 & 0.038 & 0.180 & 0.107 & 0.019 & 0.055 \\
Netherlands & 0.458 & 0.257 & 0.202 & 0.041 & 0.160 & 0.088 & 0.011 & 0.062 \\
Finland & 0.417 & 0.223 & 0.194 & 0.048 & 0.146 & 0.087 & 0.016 & 0.044 \\
France & 0.469 & 0.292 & 0.177 & 0.021 & 0.157 & 0.099 & 0.018 & 0.039 \\
Denmark & 0.412 & 0.245 & 0.167 & 0.036 & 0.131 & 0.055 & 0.024 & 0.052 \\
Germany & 0.421 & 0.254 & 0.167 & 0.047 & 0.119 & 0.089 & 0.006 & 0.024 \\
UK & 0.475 & 0.323 & 0.153 & 0.031 & 0.121 & 0.044 & 0.005 & 0.073 \\
Norway & 0.379 & 0.235 & 0.144 & 0.040 & 0.104 & 0.065 & 0.005 & 0.043 \\
Australia & 0.423 & 0.297 & 0.126 & 0.049 & 0.077 & 0.030 & 0.011 & 0.036 \\
Canada & 0.406 & 0.290 & 0.116 & 0.038 & 0.078 & 0.037 & 0.011 & 0.030 \\
Switzerland & 0.395 & 0.293 & 0.102 & 0.009 & 0.093 & 0.078 & 0.013 & 0.001 \\
USA & 0.447 & 0.345 & 0.102 & 0.046 & 0.056 & 0.033 & 0.002 & 0.021 \\
\hline Mean & 0.431 & 0.271 & 0.161 & 0.039 & 0.122 & 0.071 & 0.013 & 0.039 \\
\hline S
\end{tabular}

Source: Luxembourg Income Study, 2004, http://www.lisdatacenter.org/. - 'Market' denotes the primary distribution, i.e., the result of market activity before government and social security redistribution. 'Disposable' denotes the final distribution of disposable incomes. The other columns report the contributions of different policy instruments to overall redistribution (columns 4 and 5) and to redistribution through transfers (columns 6-8). All data are from the 2004 wave of the Luxembourg Income Study.

In Table 3, we focus on another narrow policy goal and order countries by their achieved absolute reductions in poverty. The poverty measure (PM) is defined as follows: First, a headcount is conducted for which the percentage number of individuals below the poverty line (HC) is calculated. The poverty line is defined as $50 \%$ of a country's median income, i.e., a relative poverty measure is used. In a second step, a poverty gap (PG) is calculated. The 
poverty gap divides the absolute difference between the mean income of the poor by the median income of the population through the median income of the population. The poverty gap thus measures how large the income difference between the mean poor and the median household is, relative to the median household's income. Finally, $(\mathrm{PM})=(\mathrm{HC}) *(\mathrm{PG})$ is calculated. To reduce poverty by these measures, government can thus either reduce the number of the poor (reduce the (HC) measure) or it can raise the average income of the poor (reduce the (PG) measure).

Table 3: Poverty Measures and Poverty Reduction in Selected OECD Countries in 2000

\begin{tabular}{llll}
\hline & Poverty measure & & Poverty reduction \\
\hline Country & Market incomes & Disposable incomes & \\
\hline Belgium & 27.7 & 4.1 & 23.6 \\
Netherlands & 26.7 & 4.5 & 22.3 \\
Sweden & 25.7 & 4.4 & 21.3 \\
Finland & 22.2 & 3.2 & 19.0 \\
Denmark & 24.1 & 5.6 & 18.5 \\
UK & 25.4 & 7.3 & 18.0 \\
France & 22.7 & 5.3 & 17.4 \\
Germany & 21.5 & 4.4 & 17.1 \\
Norway & 19.3 & 4.0 & 15.3 \\
Australia & 21.3 & 8.0 & 13.3 \\
Switzerland & 17.2 & 5.5 & 11.8 \\
Canada & 19.1 & 7.6 & 11.5 \\
USA & 20.1 & 11.6 & 8.5 \\
\hline Mean & 22.5 & 5.8 & 16.7 \\
\hline
\end{tabular}

Source: Luxembourg Income Study, 2004.

According to Table 3, most countries indeed achieve substantial reductions in poverty through their redistributive policies. Also, the ranking of countries is very similar to the ranking in Table 2: Countries that are relatively more active in redistributing income are also more active in organizing targeted transfers to poor individuals.

\section{The econometric analysis}

\subsection{The econometric approach and the data}

Instead of analyzing different spending or taxing instruments, we focus on the actual (re-) distribution achieved by overall governmental activity measured by (differences in) Gini coefficients. We proceed in two steps in order to test the comparative impact of alternative constitutional frameworks on income (re-)distribution. First, a cross section of 70 countries (listed in the Appendix) at the end of the 1990s is used to find out whether there are differences in the distribution of final (disposable) incomes that can be attributed to the 
constitutional differences outlined in Section 2. As this cross country dataset, which has been collected by Persson and Tabellini (2003), does not contain any measure of the primary (market) income distribution, it is not possible to infer with certainty whether constitutional differences also affect income redistribution. This analysis thus allows only a first impression as to the effects of institutional differences.

A closer look at redistribution is taken with the second step of the analysis. For a small sample of 13 OECD countries (listed in the notes to Table 5) between 1981 and 1998, a yearly panel dataset is constructed on the basis of data provided by the Luxembourg Income Study (Atkinson et al. 1995) which enables us to analyze the impact of institutional factors on the primary and final income distributions as well as on fiscal redistribution. This dataset has another drawback, however, as the 13 countries comprise too small numbers of presidential systems, or systems with plurality rule, such that how that regime type affects income redistribution cannot be tested. However, these data allow us to focus on differences in fiscal decentralization.

In general, the following econometric model is used:

$$
\text { GINI }_{i t}=\beta_{0}+\beta_{1} \operatorname{CONST}_{i t}+\beta_{2} V_{i t}+u_{i t}
$$

where GINI $_{i t}$ stands for the different Gini indexes used as proxies for income redistribution. In the first step of the analysis, i.e., in the next section, we analyze Gini coefficients for the final income distribution, i.e., the distribution of disposable income. In the second step of the analysis, primary and final income distributions as well as fiscal redistribution as the difference between these two income distributions are analyzed.

Equation (1) implies that the resulting distribution of disposable incomes is a function of constitutional differences, CONST $T_{i t}$ : As constitutional differences, we consider the differences between parliamentary and presidential democracies, plurality rule and proportional representation, and, finally, federal and unitary countries. In each step of the analysis, income (re-) distribution is additionally explained by several control variables $V_{i t}$. They vary depending on the available dataset and are subsequently introduced. However, a basic set of control variables remains largely unchanged across regressions, namely an income variable, a proxy for educational attainment and a population variable. The parameter of interest is $\beta_{1}$, while $u_{i t}$ denotes the error term. Subscript $i$ indicates the cross section units, while $t$ indicates the years. 


\subsection{Political institutions and the distribution of disposable incomes}

In order to analyze the relation between presidential versus parliamentary democracy or plurality rule versus proportional representation on the one hand and the distribution of disposable income measured by Gini-coefficients on the other hand, the cross section data are averaged over the period from 1990 to 1998 (or shorter periods when data are unavailable for earlier dates) in order to eliminate the influence of short-term shocks in particular years.

The first variable of interest in our investigation is a dummy variable that is equal to one in presidential regimes, and zero otherwise; only those regimes in which the government is immune from a confidence vote of the parliament are considered as presidential. Second, a dummy variable for electoral systems is included which equals 1 if all members of the lower house are elected under plurality rule, and zero otherwise. These two variables are discussed in more detail in Persson and Tabellini (2003: ch. 4). Third, the econometric model contains a dummy variable that is equal to one if the country has a federal political structure, and zero otherwise. It should be noted that degrees of sub-federal tax and spending autonomy and thus fiscal competition in federations are not captured by this dummy variable. Moreover, there are also many unitary states, such as some Nordic countries with strong fiscal competencies at the local level, which are not accounted for when a simple dummy variable is used.

The basic control variables are log income (natural log of real GDP per capita in constant dollars), the total enrolment in primary and secondary education (as a percentage of the relevant age group in the population), the natural log of total population (in millions), the population proportion between the ages of 15 and 64, and the population proportion 65 years years old and above from total population. The selection of these variables is justified by the broad literature on the determinants of government spending and spending composition (Feld and Kirchgässner 2001; Persson and Tabellini 2003), but also from previous public choice analyses of income redistribution (Feld, Fischer and Kirchgässner 2010).

In addition, the model is augmented by further explanatory variables in order to test the robustness of our results on institutional differences. Central government spending and revenue as a percentage of GDP are included, as well as ethno-linguistic fragmentation, the Gastil index of civil liberties and political rights, trade openness and the age of democracy. The choice of these additional control variables is motivated by theoretical reasoning, e.g., because they are related to political institutions. For example, ethno-linguistic fragmentation 
may affect the income distribution directly or indirectly through the choice of particular political institutions.

The model is estimated by OLS and the results are reported in Table 4. As can be seen from the bottom of the table, the variation in the Gini index of the disposable income distribution is fairly well explained. Even the simplest model with the baseline control variables explains almost $60 \%$ of the variation of the Gini index according to the adjusted $\mathrm{R}^{2}$. Also, the Fstatistics indicate that the model cannot be rejected on any conventional significance level. Please note for an interpretation of the estimated coefficients that a Gini-coefficient closer to zero indicates a more equal (market or disposable) income distribution. A negative sign of a coefficient thus indicates a reduction of inequality while a positive sign indicates that a variable increases inequality.

The results in Model (1) of Table 4 imply that countries with a higher real GDP per capita or a higher enrollment in primary and secondary education have a less equally distributed disposable income (significant at the $5 \%$ or $1 \%$ levels respectively), while a country's population size has no significant effect on the income distribution. The direction of causation is particularly difficult to discern for the relation between GDP and inequality. It may be that in more affluent societies, where even relatively poor individuals enjoy high absolute levels of consumption, tolerance towards inequality increases and the political demand for redistribution declines, for example, because in these countries, the market process that generates an income distribution is considered generally fair (Bjørnskov et al. 2013). It may, however, also be the case that entrepreneurial societies generate both inequality (through successful entrepreneurship) and affluence. 
Table 4: Cross Country Regressions of the Gini-Index on Electoral Systems and Forms of Government, OLS, 70 Countries, Averages for the Period 1990 to 1998

\begin{tabular}{|c|c|c|c|c|c|c|c|c|}
\hline & (1) & (2) & (3) & (4) & (5) & (6) & (7) & (8) \\
\hline \multirow[t]{2}{*}{ Log Income } & $3.067 * *$ & $3.262 * *$ & $3.556^{* *}$ & $4.033 * *$ & $3.708 *$ & $3.901 * *$ & $4.191 * *$ & $4.529 * *$ \\
\hline & {$[2.29]$} & {$[2.45]$} & {$[2,0]$} & {$[2.30]$} & [1.99] & {$[2.05]$} & {$[2.18]$} & {$[2.17]$} \\
\hline Enrolment in & $0.185^{* * *}$ & $0.171^{* *}$ & $0.169 * *$ & $0.204 * * *$ & $0.210 * * *$ & $0.225 * * *$ & $0.217 * * *$ & $0.218^{* * *}$ \\
\hline Primary and Secondary Education & {$[2.64]$} & {$[2.45]$} & {$[2.36]$} & {$[2.77]$} & {$[2.81]$} & {$[2.84]$} & {$[2.73]$} & {$[2.71]$} \\
\hline \multirow[t]{2}{*}{ Log Population } & 0.043 & -0.071 & -0.118 & 0.633 & -0.006 & -0.136 & -0.627 & -0.562 \\
\hline & {$[0.08]$} & {$[-0.13]$} & {$[-0.19]$} & {$[0.11]$} & {$[-0.01]$} & {$[-0.21]$} & {$[-0.76]$} & {$[-0.67]$} \\
\hline Proportion of & $-0.589 * *$ & $-0.498^{*}$ & $-0.523^{*}$ & -0.269 & -0.271 & -0.316 & -0.218 & -0.237 \\
\hline Population of Age 15 to 64 Years & {$[-2.21]$} & {$[-1.85]$} & {$[-1.79]$} & {$[-0.94]$} & {$[-0.93]$} & {$[-1.05]$} & {$[-0.69]$} & {$[-0.73]$} \\
\hline Proportion of & $-1.837 * * *$ & $-1.733 * * *$ & $-1.754 * * *$ & $-1.964 * * *$ & $-1.987 * * *$ & $-1.880 * * *$ & $-1.869 * * *$ & $-1.848 * * *$ \\
\hline Population above 64 Years & {$[-6.34]$} & {$[-5.79]$} & {$[-5.40]$} & {$[-5.23]$} & {$[-5.22]$} & {$[-4.47]$} & {$[-4.44]$} & {$[-4.33]$} \\
\hline \multirow[t]{2}{*}{ Presidential Regimes } & - & $3.522 *$ & 3.635 & $4.816^{* *}$ & $4.696 * *$ & $4.637^{*}$ & $4.573^{*}$ & $4.916^{*}$ \\
\hline & & [1.69] & {$[1.60]$} & {$[2.08]$} & {$[2.00]$} & {$[1.97]$} & {$[1.94]$} & {$[1.96]$} \\
\hline \multirow[t]{2}{*}{ Plurality Rule } & - & -0.408 & -0.538 & -0.719 & -0.369 & -0.118 & -0.084 & 0.040 \\
\hline & & {$[-0.24]$} & {$[-0.29]$} & {$[-0.39]$} & {$[-0.19]$} & {$[-0.06]$} & {$[-0.04]$} & {$[0.02]$} \\
\hline \multirow{2}{*}{ Federal Political Structure } & - & - & 0.226 & -0.622 & -0.368 & -0.186 & -0.135 & -0.169 \\
\hline & & & {$[0.08]$} & {$[-0.25]$} & {$[-0.14]$} & {$[-0.07]$} & {$[-0.05]$} & {$[0.06]$} \\
\hline \multirow{2}{*}{$\begin{array}{l}\text { Central Government Expenditure } \\
\text { as a Percentage of GDP }\end{array}$} & - & - & - & -0.013 & 0.002 & 0.005 & -0.091 & -0.092 \\
\hline & & & & {$[0.05]$} & {$[0.01]$} & {$[0.02]$} & {$[-0.34]$} & {$[-0.35]$} \\
\hline \multirow{2}{*}{$\begin{array}{l}\text { Central Government Revenue } \\
\text { as a Percentage of GDP }\end{array}$} & - & - & - & 0.039 & 0.024 & 0.015 & 0.139 & 0.137 \\
\hline & & & & {$[0.18]$} & {$[0.11]$} & {$[0.07]$} & {$[0.55]$} & {$[0.54]$} \\
\hline Ethnolinguistic & - & - & - & - & -2.201 & -3.072 & -1.890 & -1.393 \\
\hline Fractionalization & & & & & {$[-0.55$} & {$[-0.71]$} & {$[-0.42]$} & {$[-0.30]$} \\
\hline \multirow{5}{*}{$\begin{array}{l}\text { Gastil Index of } \\
\text { Civil Liberties and Political Rights } \\
\text { Trade Openness (Exports plus Imports } \\
\text { of Goods and Services Divided by GDP) }\end{array}$} & - & - & - & - & - & 0.756 & 1.352 & 1.157 \\
\hline & & & & & & {$[0.61]$} & {$[0.98]$} & {$[0.79]$} \\
\hline & - & - & - & - & - & - & -0.295 & -0.028 \\
\hline & & & & & & & {$[-0.99]$} & {$[-0.93]$} \\
\hline & - & - & - & - & - & - & - & -2.190 \\
\hline Age of Democracy & & & & & & & & {$[-0.43]$} \\
\hline Constant & 49.197 & 41.334 & 40.876 & 17.938 & 21.071 & 18.814 & 12.006 & 10.588 \\
\hline Obs. & 70 & 70 & 68 & 63 & 63 & 63 & 63 & 63 \\
\hline Adj. $R^{2}$ & 0.595 & 0.603 & 0.581 & 0.617 & 0.612 & 0.607 & 0.607 & 0.602 \\
\hline F-statistics & 21.28 & 15.95 & 12.61 & 10.99 & 9.89 & 8.98 & 8.36 & 7.65 \\
\hline RMSE & 6.633 & 6.571 & 6.712 & 6.085 & 6.127 & 6.165 & 6.166 & 6.218 \\
\hline
\end{tabular}

Notes: The numbers in parentheses are absolute values of the estimated t-statistics. '***’, ‘**', or ‘*’ indicates significance at the1, 5, or 10 percent levels, respectively. 
Larger proportions of older people and people in the working age both imply a significantly more equal distribution of disposable incomes. This implies in turn that countries with a larger share of young people have a less equal income distribution. Regarding the coefficients of both variables, it is obvious that proportionally more older people (and thus pensioners) are associated with a more equal income distribution. One reason for this may simply be that young individuals, who either attend school, independent study, or are at the very beginning of their professional careers typically earn no or very low incomes. An increase in the number of young people would thus immediately raise the value of the Gini coefficient. ${ }^{1}$ This is also a plausible interpretation for the effect reported for enrollment in primary and secondary education. In addition to this, policy choices are also likely to depend on demographics. An increase in the share of older individuals, i.e., of those who receive a pension or expect to receive it relatively soon, may also raise the probability of redistributive policies targeted towards pensioners.

Model (2) includes the dummy variables for presidential systems and plurality rule. Presidential systems have a less equal final income distribution, consistent with results on welfare spending reported above. However, this effect is only marginally significant on the $10 \%$ significance level. It loses significance when the dummy variable for federalism is introduced into the model, but regains significance (up to higher levels) with the inclusion of other control variables. It should be noted that these effects are not the result of the smaller sample size.

The dummy variable for plurality rule is, however, not significant on any of the specifications. It has an unanticipated positive sign, which reverses when the age of democracy is included in the model. This is somewhat surprising, given that Milesi-Ferreti, Perotti and Rostagno (2002) found a positive and significant effect of the degree of proportionality of an electoral system on the magnitude of transfer payments. A possible explanation may be that MilesiFeretti et al. choose the funds used for redistribution as their dependent variable, while we choose inequality of disposable incomes, i.e., a measure of actually achieved equalization. In other words, the incongruence between the two sets of results may be an indication that higher transfers in countries with more proportional electoral systems are not necessarily associated with higher actual equalization of incomes - which in turn is an indication that more proportional systems tend to redistribute in a less targeted fashion to the poor.

\footnotetext{
${ }^{1}$ This has been pointed out by an anonymous referee.
} 
Less surprising, the dummy variable for federal states does not have any significant impact in these regressions. As mentioned already above, such a crude dummy variable is not able to distinguish between federations organized as systems with strong fiscal competition, such as Switzerland, the United States or Canada, and federations with a cooperative or centralized form of federalism, such as Germany, Austria or Australia.

It should be noted at this stage as well that none of the additional control variables that are included to test the robustness of our results has any significant impact on the Gini index of disposable income distribution. This holds for central government spending and revenue, the inclusion of which increases the significance of the dummy variable for presidential systems to the 5\% level. It also holds for trade openness, ethno-linguistic fractionalization, the Gastil index of civil liberties and political rights and for the age of democracy.

Each of these variables has its rationale. For example, there is a broad discussion in the literature about whether more open economies face stronger demands for income redistribution by those groups most negatively affected by globalization (Rodrik 1998). Ethno-linguistic fractionalization is connected to the arguments brought forward by Roemer and van der Straeten (2006). The Gastil index attempts to control for democracy as such, and the age of democracy aims at controlling indirectly for the impact of interest groups. As Olson (1982) argued, a stable democratic regime that persists over a longer time period invites interest groups to exert more and more influence, which finally leads to a sclerotic society. Interpreting the lack of impact of these variables, it should be noted that each one could still affect income redistribution overall or by single redistributive measures as the final income distribution is the interaction between the primary income distribution and income redistribution. The fact that they do not influence the distribution of disposable incomes is still remarkable enough.

\subsection{Fiscal autonomy and income (re-)distribution}

In order to explore more properly the relation between fiscal competition and income (re-) distribution, a different approach is now taken. The data provided by the Luxembourg Income Study (see Atkinson et al. 1995) allows us to construct a panel dataset at least for a few, in our case 13, OECD countries (see also Table 2). The most important advantage of this dataset is the possible distinction between primary and final income distributions which allows for an explicit analysis of the fiscal redistribution efforts undertaken by the government. The most important disadvantage is the smaller sample size in the cross section domain, which does not 
allow us to test for the effect of constitutional differences that featured prominently in the previous subsection, nor to employ modern panel data techniques, in particular to estimate fixed effects models. We thus first use the annual panel data with time fixed effects, but no country fixed effects, and then also conduct our analysis on the basis of six-year-averages of that data for the three periods 1981-1986, 1987-1992 and 1993-1998.

Nevertheless, insights concerning the impact of fiscal competition on income (re-)distribution could be gained by using these data. Hence, they are matched with recent data collected by Stegarescu (2004) on the basis of the methodology developed by the OECD (1999). Owing to the unsatisfactory measurement of federalism by simple dummy variables, the share of subcentral government spending in total government spending often is adopted as a variable to capture the fiscal autonomy of state and local governments. OECD (1999) and Stegarescu (2004) proceed further by focusing on taxation. The OECD (1999) measures the share of subcentral tax revenue in total tax revenue for taxes that could be influenced by the state or local governments. This measure permits differentiating the fiscal autonomy of state and local governments either with regard to (1) tax rates only, tax bases only or both, (2) but also the influence of state and local governments on joint taxation systems and (3) on the determination of inter-governmental grants. Stegarescu (2004) applies the OECD approach not only to single years, but constructs a yearly panel dataset from 1973 to 1998 and adds further countries. This approach finally leaves three main indicators of fiscal autonomy with respect to taxation in addition to the fiscal decentralization measure usually considered on the spending side, i.e., the share of sub-central spending in total spending. The three measures are: (1) the share of sub-central revenue in total revenue of which the state and local governments (SLG) can determine tax rates or bases; (2) the share of sub-central revenue in total revenue of which state and local governments can co-determine revenue from joint taxation systems in addition to the former indicator; and, in addition to the revenue share as calculated before, (3) the share of sub-central revenue in total revenue of which the state and local governments have a say on grants.

Using these variables, we estimate a model in which the different Gini indexes (primary income distribution, final income distribution, fiscal redistribution) are explained by GDP per employee, public education spending, population growth, expenditure decentralization as usually measured, revenue decentralization with SLG autonomy on tax rates or bases, revenue decentralization with a SLG say on tax rates, bases or joint taxes, and revenue decentralization with a SLG say on tax rates, bases, joint taxes or grants. Finally, openness is 
included as a variable for a robustness check. We include period fixed effects when employing yearly panel data as the data points in the cross section domain are too few to estimate meaningful models with country fixed effects. When we use six-year-averages, we also estimate the model with period fixed effects. Given that the constitutional basis for tax autonomy does not vary much across time, the effect of tax autonomy on income redistribution stems mainly from the cross-section variation. The six-year-averages are thus the more reliable estimates.

Table 5: Panel Regressions of the Gini-Index of Primary and Disposable Income Distribution on Fiscal Decentralization, Pooled Regressions with Time Fixed Effects, 13 OECD Countries, 1981 to 1998

\begin{tabular}{|c|c|c|c|c|c|c|}
\hline & $\begin{array}{l}\text { Primary } \\
\text { (1a) }\end{array}$ & $\begin{array}{l}\text { Disposable } \\
\text { (1b) }\end{array}$ & $\begin{array}{l}\text { Primary } \\
(2 a)\end{array}$ & $\begin{array}{l}\text { Disposable } \\
\text { (2b) }\end{array}$ & $\begin{array}{l}\text { Primary } \\
(3 a)\end{array}$ & $\begin{array}{l}\text { Disposable } \\
\text { (3b) }\end{array}$ \\
\hline GDP per Employee & $\begin{array}{l}0.001^{* * *} \\
{[3.42]}\end{array}$ & $\begin{array}{l}0.002^{* * *} \\
{[4.71]}\end{array}$ & $\begin{array}{l}0.001^{* * *} \\
{[3.94]}\end{array}$ & $\begin{array}{l}0.002^{* * *} \\
{[6.87]}\end{array}$ & $\begin{array}{l}0.001^{* * *} \\
{[4.27]}\end{array}$ & $\begin{array}{l}0.003^{* * *} \\
{[10.05]}\end{array}$ \\
\hline Government Education & -0.001 & $-0.013 * * *$ & -0.002 & $-0.018 * * *$ & -0.001 & $-0.015 * * *$ \\
\hline Spending & {$[-0.21]$} & {$[-6.71]$} & {$[-1.33]$} & {$[-10.65]$} & {$[-0.87]$} & {$[-11.76]$} \\
\hline $\begin{array}{l}\text { Population Growth } \\
\text { in Percent }\end{array}$ & $\begin{array}{l}-0.001 \\
{[-0.84]}\end{array}$ & $\begin{array}{l}0.000 \\
{[0.12]}\end{array}$ & -0.001 & $\begin{array}{l}0.001 \\
{[074]}\end{array}$ & $\begin{array}{l}-0.001 \\
{[-0.89]}\end{array}$ & $\begin{array}{l}-0.000 \\
{[-007]}\end{array}$ \\
\hline Expenditure & $-0.001 * * *$ & $0.001 * * *$ & $-0.001^{* * * *}$ & $0.001 * * *$ & $\begin{array}{l}{[-0.89]} \\
-0.001 * * *\end{array}$ & $\begin{array}{l}{[-0.0 /]} \\
0.001 * * *\end{array}$ \\
\hline Decentralization & {$[-5.63]$} & {$[4.47]$} & {$[-4.96]$} & [7.17] & {$[-5.79]$} & {$[4.26]$} \\
\hline Revenue Decentra- & $-0.001 * * *$ & 0.000 & -0.000 & $0.001 * * *$ & -0.000 & $0.001 * * *$ \\
\hline $\begin{array}{l}\text { lization (tax rates } \\
\text { and bases) }\end{array}$ & {$[-4.60]$} & {$[0.57]$} & {$[-1.04]$} & [6.91] & {$[-1.27]$} & [8.09] \\
\hline $\begin{array}{l}\text { Revenue Decentra- } \\
\text { lization (tax rates } \\
\text { and bases or joint } \\
\text { taxation) }\end{array}$ & - & - & $\begin{array}{l}0.001 \\
{[1.19]}\end{array}$ & $\begin{array}{l}0.004^{* * *} \\
{[2.94]}\end{array}$ & $\begin{array}{l}0.002 \\
{[1.52]}\end{array}$ & $\begin{array}{l}0.005^{* * *} \\
{[5.15]}\end{array}$ \\
\hline $\begin{array}{l}\text { Revenue Decentra- } \\
\text { lization (tax rates } \\
\text { and bases, joint taxation } \\
\text { or fiscal equalization) }\end{array}$ & - & - & $\begin{array}{l}-0.002 * \\
{[-1.70]}\end{array}$ & $\begin{array}{l}-0.006 * * * \\
{[-4.29]}\end{array}$ & $\begin{array}{l}-0.002 * * \\
{[-2.00]}\end{array}$ & $\begin{array}{l}-0.007 * * * \\
{[-6.71]}\end{array}$ \\
\hline Openness $(* 1000)$ & - & - & - & - & $\begin{array}{l}-0.182 * * * \\
{[-2.99]}\end{array}$ & $\begin{array}{l}-0.672 * * * \\
{[-12.47]}\end{array}$ \\
\hline Constant & 0.428 & 0.216 & 0.435 & 0.235 & 0.445 & 0.272 \\
\hline Adj. $\mathrm{R}^{2}$ & 0.484 & 0.282 & 0.513 & 0.508 & 0.530 & 0.711 \\
\hline SER & 0.026 & 0.034 & 0.025 & 0.028 & 0.024 & 0.022 \\
\hline No. of Obs. & 234 & 234 & 234 & 234 & 234 & 234 \\
\hline F-statistic & 11.016 & 5.208 & 11.353 & 11.171 & 11.650 & 24.226 \\
\hline
\end{tabular}

For Notes see Table 4. - The same econometric models are estimated for the primary and the disposable income distribution and are for better comparison paired in two columns each as a and b models. The 13 OECD countries are Australia, Belgium, Canada, Denmark, France, Finland, Germany, the Netherlands, Norway, Sweden, Switzerland, the United Kingdom and the United States.

Results for the Gini index of the primary and disposable income distributions are presented in Table 5. We show the same models for both income distributions in comparison in each pair of columns. The first model contains only the basic control variables, expenditure and revenue decentralization with sub-central autonomy over tax rates or bases. This model is followed by the inclusion of the other measures of sub-central tax autonomy. Finally, these models are 
augmented by openness. In line with the previous subsections, we find that countries with a higher GDP per employee, i.e., greater overall labor productivity, have a less equal primary and disposable income distribution. Education or population growth do not have any robustly significant impact on the primary income distribution, but public education spending is significantly negatively associated with the Gini index of the disposable income distribution.

The primary income distribution is significantly more equal in countries with higher spending or revenue decentralization. This particularly holds with respect to more taxing autonomy. The relationship becomes statistically more uncertain if the revenue from joint taxation or from grants is also included. This is indicated by the declining significance in model (1a) and (2a) of Table 5. These results are robust to the inclusion of openness, which is itself highly significant and negative (Model 3a). More open economies have a more equal primary income distribution. As the primary income distribution is the income distribution (largely) obtained due to individuals’ market activities, these results indicate that both fiscal competition within a country or trade openness as an indicator of globalization do not exacerbate the gaps between income classes.

Regarding the distribution of disposable income, indicators of fiscal decentralization are significantly negatively associated with the Gini index of the final income distribution. This holds for spending decentralization (Model 1b), but also for revenue decentralization when state and local governments can decide on tax rates or tax bases and the other indicators of revenue decentralization are included (Model 2b). A stronger participation in grant systems reduces final income inequality, as it has a significantly negative effect on the Gini index of the final income distribution. These results are largely robust to the inclusion of trade openness, which again has a significantly negative coefficient, i.e., more open economies have a more equal final income distribution (Model 3b).

Fiscal competition appears to restrict income redistribution. Whether this is actually the case can be studied explicitly by considering the difference between the Gini indexes of the primary income distribution and the distribution of disposable income measured in Gini points. The respective estimation results are reported in Table 6 both for models in which the primary income distribution is not controlled for, and for models in which it is. This is done in order to capture the differences in the demand for income redistribution that more probably occur owing to larger gaps between upper and lower income groups. According to the results reported in models (1a), (2a) and (3a) in Table 6, expenditure and revenue decentralization restrict the government's ability to redistribute income when fiscal decentralization also 
involves fiscal competition. Including the primary income distribution does not alter these results as models (1b), (2b) and (3b) in Table 6 show. The less equal is the primary income distribution, the greater the fiscal redistribution undertaken by the government is.

Nevertheless, fiscal decentralization, when accompanied by strong fiscal autonomy, is associated with significantly less fiscal redistribution. Please also note that fiscal competition induces a more equal distribution of primary income and, even though the distribution of disposable income is less equal, it remains an open question as to how the effect of fiscal competition on income distribution should be evaluated. Because measures of income redistribution usually have adverse incentive effects that impact economic growth negatively, fiscal competition might be favorable for countries with strong egalitarian preferences. A rising tide lifts all boats, and fiscal decentralization might in the long-run enable some countries to outperform those with more moderate income redistribution policies.

Table 6: Panel Regressions of Fiscal Redistribution Measured in Gini-Points on Fiscal Decentralization Without and With Controlling for the Primary Income Distribution, Pooled Regressions with Time Fixed Effects, 13 OECD Countries, 1981 to 1998

\begin{tabular}{|c|c|c|c|c|c|c|}
\hline & $\begin{array}{l}\text { Without } \\
\text { (1a) }\end{array}$ & $\begin{array}{l}\text { With } \\
\text { (1b) }\end{array}$ & $\begin{array}{l}\text { Without } \\
\text { (2a) }\end{array}$ & $\begin{array}{c}\text { With } \\
\text { (2b) }\end{array}$ & $\begin{array}{l}\text { Without } \\
\text { (3a) }\end{array}$ & $\begin{array}{l}\text { With } \\
\text { (3b) }\end{array}$ \\
\hline GDP per Employee & $\begin{array}{l}-0.001 * * \\
{[-2.40]}\end{array}$ & $\begin{array}{l}-0.001 * * * \\
{[-3.35]}\end{array}$ & $\begin{array}{l}-0.001 * * * \\
{[-3.45]}\end{array}$ & $\begin{array}{l}-0.002 * * * \\
{[-5.49]}\end{array}$ & $\begin{array}{l}-0.001 * * * \\
{[-4.65]}\end{array}$ & $\begin{array}{l}-0.002 * * * \\
{[-8.74]}\end{array}$ \\
\hline Government Education & $0.013 * * *$ & $0.013^{* *}$ & $0.016^{* * *}$ & $0.017 * * *$ & $0.014 * * *$ & $0.015^{* * *}$ \\
\hline Spending & [7.36] & {$[7.68]$} & [9.65] & [11.24] & [9.57] & [12.66] \\
\hline Population Growth & -0.001 & -0.001 & -0.001 & -0.001 & -0.001 & -0.000 \\
\hline in Percent & {$[-0.84]$} & {$[-0.64]$} & {$[-1.33]$} & {$[-1.16]$} & {$[-0.83]$} & {$[-0.36]$} \\
\hline $\begin{array}{l}\text { Gini Index of Primary } \\
\text { Income Distribution }\end{array}$ & - & $\begin{array}{l}0.319 * * * \\
{[4.16]}\end{array}$ & - & $\begin{array}{l}0.476^{* * *} \\
{[7.04]}\end{array}$ & - & $\begin{array}{l}0.605^{* * *} \\
{[11.32]}\end{array}$ \\
\hline Expenditure & $-0.002 * * *$ & $-0.001 * * *$ & $-0.002 * * *$ & $-0.001 * * *$ & $-0.001 * * *$ & $-0.001 * * *$ \\
\hline $\begin{array}{l}\text { Decentraliza- } \\
\text { tion }\end{array}$ & {$[-9.78]$} & {$[-8.01]$} & {$[-11.79]$} & {$[-10.12]$} & {$[-9.61]$} & {$[-7.13]$} \\
\hline $\begin{array}{l}\text { Revenue Decentralization } \\
\text { (tax rates } \\
\text { or bases) }\end{array}$ & $\begin{array}{l}-0.001 * * * \\
{[-4.52]}\end{array}$ & $\begin{array}{l}-0.001 * * * \\
{[-3.25]}\end{array}$ & $\begin{array}{l}-0.002^{* * *} \\
{[-7.97]}\end{array}$ & $\begin{array}{l}-0.001 * * * \\
{[-8.29]}\end{array}$ & $\begin{array}{l}-0.001^{* * *} \\
{[-8.46]}\end{array}$ & $\begin{array}{l}-0.001 * * * \\
{[-9.62]}\end{array}$ \\
\hline $\begin{array}{l}\text { Revenue Decentralization } \\
\text { (tax rates } \\
\text { or bases or joint taxation) }\end{array}$ & - & - & $\begin{array}{l}-0.002 * \\
{[-1.93]}\end{array}$ & $\begin{array}{l}-0.003^{* * *} \\
{[-2.69]}\end{array}$ & $\begin{array}{l}-0.003^{* * *} \\
{[-3.05]}\end{array}$ & $\begin{array}{l}-0.004 * * * \\
{[-4.97]}\end{array}$ \\
\hline $\begin{array}{l}\text { Revenue Decentralization } \\
\text { (tax rates or } \\
\text { bases, joint taxation or } \\
\text { fiscal equalization) }\end{array}$ & - & - & $\begin{array}{l}0.004^{* * *} \\
{[2.84]}\end{array}$ & $\begin{array}{l}0.005^{* * * *} \\
{[3.92]}\end{array}$ & $\begin{array}{l}0.004^{* * *} \\
{[3.95]}\end{array}$ & $\begin{array}{l}0.006^{* * *} \\
{[6.43]}\end{array}$ \\
\hline Openness $(* 1000)$ & - & - & - & - & $\begin{array}{l}0.489 * * * \\
{[8.07]}\end{array}$ & $\begin{array}{l}0.599 * * * \\
{[12.17]}\end{array}$ \\
\hline Constant & 0.213 & 0.076 & 0.020 & -0.008 & 0.173 & -0.096 \\
\hline Adj. $\mathrm{R}^{2}$ & 0.547 & 0.578 & 0.624 & 0.692 & 0.709 & 0.815 \\
\hline SER & 0.030 & 0.029 & 0.028 & 0.025 & 0.024 & 0.019 \\
\hline No. of Obs. & 234 & 234 & 234 & 234 & 234 & 234 \\
\hline F-statistic & 13.932 & 15.053 & 17.338 & 22.245 & 24.005 & 41.214 \\
\hline
\end{tabular}

For Notes see Table 4. - The dependent variable is the difference between the primary and the disposable income distribution measured in Gini points. The same econometric models are estimated for models with and without the primary income distribution as explanatory variable and are for better comparison paired in two columns each as a and b models. 
The econometric models shown in Table 7 always include the primary income distribution.

Now we do not use annual panel data with period fixed effects, but use the six-years-averages of our data in order to consider the fact that the underlying constitutions determining tax autonomy do not vary that much across time. The results are very much in line with the previous regressions reported in Table 6 although the reported t-statistics are in general lower. Expenditure decentralization and revenue decentralization when state and local governments can decide on tax rates or tax bases, i.e., for countries with strong tax autonomy, have a negative effect on fiscal redistribution. In countries in which there exists a cooperative element in fiscal federalism, i.e., joint taxation or grants, plays a role, fiscal redistribution is higher. This also holds when controlling for openness.

Table 7: Panel Regressions of Fiscal Redistribution Measured in Gini-Points on Fiscal Decentralization Controlling for the Primary Income Distribution, Pooled Regressions with Time Fixed Effects, 13 OECD Countries, 1981 to 1998

\begin{tabular}{lllll}
\hline & $(1)$ & $(2)$ & $(3)$ & $(4)$ \\
\hline GDP per Employee & -0.001 & $-0.002^{* *}$ & $-0.002^{* *}$ & $-0.002^{* * *}$ \\
Government Education Spending & {$[-1.25]$} & {$[-2.07]$} & {$[-2.11]$} & {$[-3.84]$} \\
& $0.0145^{* * *}$ & $0.019^{* * *}$ & $0.020^{* * *}$ & $0.017^{* * *}$ \\
Population Growth & {$[3.19]$} & {$[4.51]$} & {$[4.95]$} & {$[5.92]$} \\
in Percent & 0.000 & -0.004 & -0.002 & -0.002 \\
Gini Index of Primary Income & {$[0.02]$} & {$[-0.75]$} & {$[-0.42]$} & {$[-0.55]$} \\
Distribution & 0.245 & $0.404^{* * *}$ & $0.470^{* *}$ & $0.620^{* * *}$ \\
Expenditure Decentralization & {$[1.16]$} & {$[2.12]$} & {$[2.59]$} & {$[4.66]$} \\
& $-0.001^{* * *}$ & $-0.002^{* * *}$ & $-0.002^{* * *}$ & $-0.001^{* * *}$ \\
Revenue Decentralization (tax rates & {$[-3.02]$} & {$[-3.62]$} & {$[-3.84]$} & {$[-3.22]$} \\
or bases) & -0.001 & $-0.002^{* * *}$ & $-0.002^{* * *}$ & $-0.001^{* * *}$ \\
Revenue Decentralization (tax rates & {$[-1.41]$} & {$[-3.35]$} & {$[-3.59]$} & {$[-4.17]$} \\
or bases or joint taxation) & - & $0.002^{* * *}$ & $-0.007^{*}$ & $-0.009^{* * *}$ \\
Revenue Decentralization (tax rates or & - & {$[3.25]$} & {$[-1.76]$} & {$[-3.38]$} \\
bases, joint taxation or fiscal & & - & $0.008^{* *}$ & $0.011^{* * *}$ \\
equalization) & & & {$[2.18]$} & {$[3.90]$} \\
Openness (* 1000) & - & & & $0.617^{* * *}$ \\
Constant & & - & & {$[5.27]$} \\
\hline Adj. R ${ }^{2}$ & 0.090 & 0.010 & -0.033 & -0.122 \\
SER & 0.555 & 0.663 & 0.701 & 0.847 \\
No. of Obs. & 0.030 & 0.026 & 0.024 & 0.018 \\
F-statistic & 39 & 39 & 39 & 39 \\
\hline For Notes see Table 4. The & 9.29 & 9.91 & 20.15 \\
\hline
\end{tabular}

For Notes see Table 4. - The dependent variable is the difference between the primary and the disposable income distribution measured in Gini points.

It should be noted that owing to sub-central autonomy, it is indeed warranted to speak of fiscal competition, even though our decentralization measures prima facie capture decentralization only. A look at the previous tables reveals a consistently positive effect on redistribution for the revenue decentralization variable that includes revenue from fiscal equalization. Moving away from tax competition towards cooperative federalism with a 
strong reliance on fiscal transfers appears to reverse the incentives for policy-makers to engage in redistributive policies.

These results also facilitate the interpretation of the other regressions. For example, by themselves the results in Table 5 could also be interpreted differently: Countries with a more equal primary distribution could feel less need to redistribute through the central budget. Instead, they decentralize and allow the sub-central level to supply public goods. However, as we see in Tables 6 and 7, the negative effect of decentralization on redistribution is robust even when controlling for the primary distribution.. This lends some support to our interpretation.

\section{Concluding remarks}

In this paper, we have provided evidence on the impact of formal political institutions on the actual income redistribution achieved by the state, and on inequality in primary and disposable incomes, as measured by Gini coefficients. The main results support the view that the way income is redistributed in different countries depends also on the respective constitutional framework, which is always associated with a particular set of incentives for policy-makers, and also voters.

The cross country analysis reveals that countries with presidential systems have a (marginally) significantly less equal distribution of disposable incomes than parliamentary systems. This result is robust to the inclusion of additional explanatory variables and could thus be seen as a ceteris paribus result. Strictly speaking, this does not tell us directly how income redistribution is going on in presidential systems. Together with the well-known result from the literature that presidential systems have significantly less welfare spending, it is, however, a plausible conclusion that presidential systems allow for a less broad-based redistribution of income, and end up with higher inequality.

In contrast to presidential systems, plurality rule does not significantly affect the distribution of disposable incomes. Majoritarian systems do not end up with more inequality than systems with proportional representation, despite the fact that welfare spending on average is lower under plurality rule. More research is thus needed to find out how exactly mechanisms of income redistribution are working under plurality rule.

In this cross section analysis, we also do not observe any significant effect of a dummy variable for federalism on the distribution of disposable incomes. This is not surprising given 
that federalism can be constituted in different ways. A dummy variable is not able to distinguish between federations with more or less fiscal competition at the sub-federal levels. Moreover, fiscal competition might also occur in unitary states if local governments are fiscally autonomous. We thus have a closer look at the extent of tax autonomy using annual panel data for 13 OECD countries between 1981 and 1998 as well as six-years-averages for the same time period and its impact on income distributions. It turns out in the analysis that more tax autonomy at the sub-federal levels in those countries is associated with a significantly more equal primary income distribution, a significantly less equal distribution of disposable incomes and consequently also less fiscal redistribution as measured in Gini points. The latter result particularly holds when the primary income distribution is controlled for.

Interestingly, trade openness is associated with more equal primary and final income distributions and with significantly more fiscal redistribution. While competitive federalism and trade openness seemingly increase the chances individuals have for raising their incomes overall, competitive federalism also appears to restrain on the possibilities governments from redistributing incomes. 


\section{Acknowledgments}

A previous, less focused version of this paper has been circulated under the title "Still a Director's Law? On the Political Economy of Income Redistribution”. We thank the Institut de Recherche Européenne en Economie et Fiscalité (IREF) for funding this research. The paper has been presented at the meetings of the Public Choice Society in San Antonio, the European Public Choice Society in Athens, the Mont Pelerin Society in Prague, the European Economic Association in Milan, the International Institute of Public Finance in Maastricht, the German Economic Association in Graz, at seminars at the Istituto Bruno Leoni in Milan, at the University of Siegen and of Hagen. We thank the discussants of our paper and participants in the sessions, in particular Randy Holcombe for valuable comments and suggestions. We are also indebted to two anonymous referees and to the editor in charge of this paper, Bill Shughart, for their careful reading of an earlier version of the manuscript, and for their detailed comments. Finally, we would like to thank Heiko Burret, Ekkehard Köhler and Sarah Necker for very valuable research assistance.

\section{References}

Atkinson, A.B., Rainwater, L. \& Smeeding, T.M. (1995). Income Redistribution in OECD Countries: Evidence from the Luxembourg Income Study. Paris: OECD.

Austen-Smith, D. (2000). Redistributing Income Under Proportional Representation. Journal of Political Economy, 108(6), 1235-1269.

Bjørnskov, C., Dreher, A., Fischer, J., Schnellenbach, J. \& Gehring, K. (2013). Inequality and Happiness. When Perceived Social Mobility and Economic Reality Do Not Match. Journal of Economic Behavior and Organization, 91(1), 75-92.

Brennan, G. \& Buchanan, J.M. (1980). The Power to Tax: Analytical Foundations of a Fiscal Constitution. Cambridge: Cambridge University Press.

Buettner, T. (2006). The Incentive Effect of Fiscal Equalization Transfers on Tax Policy. Journal of Public Economics, 90(3), 477-497.

Feld, L.P. \& Kirchgässner, G. (2001). The Political Economy of Direct Legislation: Direct Democracy in Local and Regional Decision-Making. Economic Policy, 33, 329-367.

Feld, L.P. \& Schnellenbach, J. (2007). Still A Director's Law? On the Political Economy of Income Redistribution. Paris: Institut de Recherches Économiques et Fiscales.

Feld, L.P., Fischer, J. \& Kirchgässner, G. (2010). The Effect of Direct Democracy on Income Redistribution: Evidence for Switzerland. Economic Inquiry, 48(4), 817-840.

Harms, P. \& Zink, S. (2003). Limits to Redistribution in a Democracy: A Survey. European Journal of Political Economy, 19(4), 651-668.

Huber, J.D. (1996). The Vote of Confidence in Parliamentary Democracies. American Political Science Review, 90(2), 269-282. 
Kroszner, R.S. \& Stratmann, T. (1998). Interest-Group Competition and the Organization of Congress: Theory and Evidence from Financial Services' Political Action Committees. American Economic Review, 88(5), 1163-1187.

Milesi-Ferreti, G.-M., Perotti, R. \& Rostagno, M. (2002), Electoral Systems and the Composition of Public Spending. Quarterly Journal of Economics, 117(2), 609-657.

Mueller, D.C. (2003). Public Choice III. Cambridge: Cambridge University Press.

OECD (1999). Taxing Powers of State and Local Government. OECD Tax Policy Studies No. 1. Paris: OECD.

Olson, M. (1982). The Rise and Decline of Nations: Economic Growth, Stagflation, and Social Rigidities. New Haven \&London: Yale University Press.

Pauly, M.V. (1973). Income Redistribution as a Local Public Good. Journal of Public Economics, 2(1), 35-58.

Persson, T. \& Tabellini, G. (1999). The Size and Scope of Government: Comparative Politics with Rational Politicians. European Economic Review, 43(4-6), 699-735.

Persson, T. \& Tabellini, G. (2000). Political Economics. Explaining Economic Policy. Cambridge, MA: MIT Press.

Persson, T. \& Tabellini, G. (2003). The Economic Effects of Constitutions. Cambridge, MA: MIT Press.

Rodrik, D. (1998). Why Do More Open Economies Have Bigger Governments?. Journal of Political Economy, 106(5), 997-1032.

Roemer, J.E. \& van der Straeten, K. (2006). The Political Economy of Xenophobia and Distribution. Scandinavian Journal of Economics, 108(2), 251-277.

Sinn, H.-W. (2003). The New Systems Competition. Oxford: Blackwell.

Stegarescu, D. (2004). Public Sector Decentralization: Measurement Concepts and Recent International Trends. Working Paper, Mannheim: Centre for European Economic Research (ZEW).

Stigler, G.J. (1970). Director's Law of Public Income Redistribution. Journal of Law and Economics, 13(1), 1-10.

Tiebout, C.M. (1956). A Pure Theory of Local Expenditures. Journal of Political Economy, 64(5), 416-424.

Voigt, S. (2011). Positive Constitutional Economics II - A Survey of Recent Developments. Public Choice, 146(1-2), 205-256. 
Appendix The 70 countries included in the analysis of Table 4

$\begin{array}{lll}\text { Australia } & \text { Germany } & \text { Peru } \\ \text { Austria } & \text { Ghana } & \text { Philippines } \\ \text { Bahamas } & \text { Greece } & \text { Poland } \\ \text { Bangladesh } & \text { Guatemala } & \text { Portugal } \\ \text { Belarus } & \text { Honduras } & \text { Romania } \\ \text { Belgium } & \text { Hungary } & \text { Senegal } \\ \text { Bolivia } & \text { India } & \text { Singapore } \\ \text { Botswana } & \text { Ireland } & \text { Slovak Republic } \\ \text { Brazil } & \text { Israel } & \text { South Africa } \\ \text { Bulgaria } & \text { Italy } & \text { Spain } \\ \text { Canada } & \text { Jamaica } & \text { Sri Lanka } \\ \text { Chile } & \text { Japan } & \text { Sweden } \\ \text { Colombia } & \text { Luxembourg } & \text { Switzerland } \\ \text { Costa Rica } & \text { Malawi } & \text { Thailand } \\ \text { Czech Republic } & \text { Malaysia } & \text { Trinidad \& Tobago } \\ \text { Denmark } & \text { Mauritius } & \text { Turkey } \\ \text { Dominican Republic } & \text { Mexico } & \text { United Kingdom } \\ \text { Ecuador } & \text { Nepal } & \text { Ukraine } \\ \text { El Salvador } & \text { Netherlands } & \text { USA } \\ \text { Estonia } & \text { New Zeland } & \text { Venezuela } \\ \text { Fiji } & \text { Nicaragua } & \text { Zambia } \\ \text { Finland } & \text { Norway } & \text { Zimbabwe } \\ \text { France } & \text { Pakistan } & \\ \text { Gambia } & \text { Paraguay } & \\ & & \end{array}$

